\title{
Sugar and Spice, and Everything Nice: Do Female Stereotypes Supersede In-group Favoritism Among Men When Evaluating Female Criminal Suspects in News Stories?
}

\author{
Osei Appiah, Lanier Holt \\ The Ohio State University, Columbus, Ohio, U.S. \\ Katie Dale \\ Florida State University, Tallahassee, Florida, U.S. \\ Tiffany White \\ University of Georgia, Athens, Georgia, U.S.
}

\begin{abstract}
Some scholars argue that stereotypes of women as docile and non-violent result in women receiving leniency from the public compared to men who commit identical crimes. However, others assert that women who commit violent crimes violate traditional gender roles, which can lead the public to evaluate them more harshly than their male counterparts. More than 900 adults read news stories about either a woman abusing a man or a man abusing a woman before evaluating the criminal suspect. Female participants showed in-group favoritism towards criminal suspects that matched their gender. Conversely, male participants did not show a preference for their in-group. Overall, both male and female participants were more likely to believe the crime was justified, have more sympathy for the criminal suspect, assign less jail time, and have a more positive attitude towards the suspect when the criminal suspect was female vis-à-vis male. These findings were more pronounced when there was a non-fatal crime compared to a crime involving a fatality. Chivalry hypothesis and social identity theory are discussed.
\end{abstract}

Keywords: race, gender, crime, chivalry, social identity theory, news, domestic abuse

\section{Introduction}

Attention to violent crimes involving women - as either victim or perpetrator-have become an obsession for the American public. Although females are more likely to be depicted in the media as victims (Brennan, 2009), popular television crime-reality series such as Deadly Women, Snapped, and Fatal Vows, feature violent female criminals who have either murdered or attempted to murder their spouse or male partner. These shows along with news stories of women offenders have likely led to heighten public interest.

This fascination with female offenders is mirrored in news media coverage, as attention to high profile

Osei Appiah, Ph.D., Professor and Associate Director, School of Communication, The Ohio State University.

Lanier Holt, Ph.D., Assistant Professor, School of Communication, The Ohio State University.

Katie Dale, Ph.D., Visiting Professor, Florida State University.

Tiffany White, Ph.D., Lecturer, Department of Communication, University of Georgia. 
cases in which women have committed or been charged with murder (e.g., Jodi Arias, Amanda Knox, Casey Anthony), have remained at the forefront of news coverage for the past several years. In fact, the rising coverage of violent female offenders in the news media is believed to enhance the news worthiness of stories (Berrington \& Honkatukia, 2010). Although some scholars have questioned the extent to which news media accurately reflect societal crime and the typic al criminal offender (Brennan \& Vandenberg, 2009), actual crime statistics re-affirm what media accounts suggest - the rate of female criminality is rising, and with it the number of women incarcerated is increasing drastic ally as well (Koons-Witt, Sevigny, Burrow, \& Hester, 2014). Despite this bourgeoning media attention given to violent women, and the increase in the amount of crime committed by women, scholarly attention to how these women are perceived, compared to their male counterparts, has been lacking.

This study looks to provide practical and theoretical value. Central to the concept of legal jur isprudence is equality under the law. However, very little is known about female criminals. Also, very little is known about the psychological mechanisms at play when people are exposed to media messages that portray male compared to female suspects charged with committing a violent crime. This study aims to fill that gap in knowledge. This study compares how female versus male suspects are perceived after harming or killing their partner in domestic abuse cases whereby the suspect invokes self-defense as a justification for his/her action.

Previous analyses of how female criminals are perceived have been inconclusive or contradic tory. Some have argued that women who commit violent crimes not only violate the law, but also societal standards for women of frailty, demureness, and gentility, and are thus punished more severely than men who commit similar or identical crimes (Elgot, 2014; Koons-Witt et al., 2014; Nooruddin, 2007). However, others argue that the stereotypical characterization of women as docile and non-violent results in women receiving preferential treatment by jurors, judges, and the general public compared to men who commit identical crimes (Albonetti, 2011; Daly \& Bordt, 1995; Daly \& Tonry, 1997; Steffensmeier, Kramer, \& Streifel, 1993). We argue the latter most accurately reflects the public's response particularly in criminal cases whereby the female assailant claims self-defense.

As a result of the aforementioned dichotomy, questions still remain regarding female criminals, specifically: Are there specific criminal offenses that may lead to variability in the public's judgment of female offenders? That is, are women who commit violent crimes, particularly crimes against domestic partners, judged harsher, more favorably or no differently than men who commit the same offense? This study will also examine whether men and women judge criminal suspects engaged in violence against a domestic partner differently based on whether the suspect is an in-group our out-group member. Specifically, do women display more in-group favoritism for a criminal suspect who is female compared to a criminal suspect who is male? Similarly, do men judge male offenders any differently than female offenders?

Media provide the primary lens by which most people come to view the world and shape their perception of criminality (Lowry, Nio, \& Leitner, 2003; Romer, Jamieson, \& Aday, 2003). In providing a better understanding of how people perceive male versus female suspects via media, the study provides a clearer understanding of why society as a whole perceives female suspects differently than their male counterparts. Further, in examining these differences we may also ascertain if these differences in perception are just a byproduct of traditional media coverage of females vis-à-vis males, or are these differences based in the fundamentally different way people perceive women based on their traditional roles in society. 


\section{Violence and Media Contextualization of Women as Victims}

Violent behavior can rarely be taken at face value, as there are layers to its interpretation. According to May (1999), violence is accompanied by social meaning that is tied to ideas of culpability and victimization, both of which are influenced by social processes and normative assumptions about the social actor. As such, individuals' interpretation of violent acts are linked to stereotypical beliefs about how a gender "should" behave. In the case of women, this has meaningful implications concerning how others view them and their actions.

The idea of a violent or aggressive woman seems shocking for many. Largely, the act of aggression is believed to be counterintuitive to what it means to be a woman, and this is so engrained in society that when women do demonstrate violent behavior they are perceived as going against their nature or natural instincts (Paape, 1998). Gilbert (2002) argued that women who engage in violent behavior "fail to conform to the gendered norms of our culture" (p. 1274), which causes such women to be viewed as anomalies within their own gendered group. Even those inclined to violence have been encouraged to regulate and suppress such urges via social and cultural conditioning (Paape, 1998).

In cases where women commit violent acts the news media through implicit visual imagery and narratives often characterize women offenders as not fully responsible for their actions, which garners sympathy from the public (Brennan \& Vandenberg, 2009). In fact, content analyses of news articles featuring female offenders reveal women are more likely than males to be portrayed as victims than perpetrators (Grabe, Trager, Lear, \& Rauch, 2006; Naylor, 2001). Moreover, news stories about female criminals often contain excuses for female offenders and are likely to convey a favorable, sympathetic position (Brennan \& Vandenberg, 2009). This may be particularly true in cases of domestic disputes or intimate partner violence (IPV), where women are more commonly victims than men (Rennison, 2003) but are also more likely than men to say they use violence as a means of self-defense in domestic abuse incidents (Barnett, Lee, \& Thelen, 1997).

Considering the perceived role of women as victims, it is not surprising that there is a double-standard regarding who is perceived to be the aggressor in domestic abuse cases (Campbell, 1993). Scholars have found that in domestic abuse cases across the U.S., there is a tendency to excuse violent behaviors done by women and often put the onus of responsibility on men (Dunn, 1993; Messing \& Heeren, 2004). Consequently, while there is an emphasis on reducing male violence against women, stereotypes of women as passive may lead people to overlook the possibility that women can be perpetrators of violent acts as well (Robertson \& Murachver, 2009).

\section{Female Stereotype as Passive and Non-violent}

Our behavioral expectations and stereotypical characterizations tend to influence our perception of others (Hackett, Day, \& Mohr, 2008). Stereotypes are generalizations indiscriminately attributed to all members within a group (Tamborini, Mastro, Chory-Assad, \& Huang, 2000), which can be automatically activated by mere exposure to a person from a different group (Devine, 1989) even without one's awareness (Bargh, 1996; Sassenberg \& Moskowitz, 2005). Historically, stereotypes have led to unjust and unfair discrimination and prejudicial treatment against members from minority and stigmatized groups (Dixon \& Linz, 2000). However, women offenders may benefit from long-held beliefs that characterize them as chaste, passive, fragile, prudent, and gentle (Pollak, 1950; Young, 1986). That is, people may be guided by such stereotypes and display leniency and preferential treatment tow ards women who commit violent acts during domestic partner disputes. 
This logic ties directly to the chivalry hypothesis. This theoretical framework in conjunction with social identity theory and attribution theory, may be quite useful in understanding the intersection between gender stereotypes, criminal suspects, and people's judgments towards male and female criminal suspects.

\section{Theoretical Framework}

There are three important theoretical framew orks that may best explain the psychological mechanisms at work when men and women evaluate gender-specific criminal offenders. The first is the chivalry hypothesis, which is guided by a person's gender stereotypes. The second is social identity theory, which suggests people have a natural tendency to favor one's own group and to derogate relevant out-groups. The third is attribution theory, which categorizes a person's behavior as a result of either personal characteristics or external factors. Together, these framew orks give us a better understanding of how the gender of a participant intersects with the gender of the offender and the type of crime committed (e.g., fatal or non-fatal domestic abuse) to impact readers' evaluations of criminal suspects.

\section{Chivalry Hypothesis}

Koons-Witt (2002) argues that chivalry is grounded in the notion of traditional gender stereotypes and expectations of women. The chivalry hypothesis explains, in part, why men may respond either indifferently or more positively to female criminal suspects compared to male criminal suspects. The chivalry hypothesis states that women should be protected from prison and the criminal justice system and treated with more leniency than their male counterparts (Belknap, 2007; Bickle \& Peterson, 1991; Franklin \& Fearn, 2008; Moulds, 1980; Koons-Witt et al., 2014). This perspective posits that leniency or preferential treatment is given to women as long as they adhere to traditional gender roles (Koons-Witt et al., 2014). This perspective implies that women will be handled more leniently by men in part because women are perceived as less culpable, less likely to be recidivists and in greater need of protection from the justice system (Nooruddin, 2007). The chivalry hypothesis also assumes that men in particular will consider women as less likely to pose a threat to the community and will factor in women's role as caregivers quite heavily in their judgment of female offenders, which in turn informs male jurors' decisions about guilt, and their decisions about sentencing female suspects (Nooruddin, 2007).

Scholars have argued that some crimes committed by women may be considered a greater violation of traditional female gender roles than others, and therefore are often deemed unw orthy of chivalrous treatment (Branscombe \& Owen, 1991, pp. 1567-1568). For example, women committing crimes that are more associated with their gender (e.g., minor property crimes) often receive lesser sentences than men. However, women who commit more egregious crimes that are often associated with men (e.g., felonies, armed robbery, murder) are often treated equally, if not more harshly than men (Koons-Witt et al., 2014). However, harsh evaluations of women are unlikely to occur in domestic abuse cases, particularly when women invoke self-defense as an excuse for their criminal actions. Women who claim self-defense are not seen as fully responsible for their violent act (Brennan \& Vandenberg, 2009).

\section{Attribution Theory}

Stereotypes play a role in observers' perceptions of the attribution of crime. That is, whether a crime committed by a person is attributed to internal, dispositional factors or external, situational factors is important. Given gender stereotypes, people are likely to perceive female suspects as being less culpable for their crime than their male counterparts. 
Attribution theory helps explain why people have different perceptions. According to Heider (1958), attribution theory assumes people attribute actions to internal and external causes (Heider, 1958; Templeton \& Hartnagel, 2012). Internal factors include one's personal disposition and attitudes, such that crime is a state of mind attributed to the offender's character, making some people predisposed to commit crime and worthy of punishment (Unnever, Cochran, Cullen, \& Applegate, 2010). In contrast, external attribution considers the offender's environment as a contributing influence on criminal behavior (Grasmick \& McGill, 1994), such that offenders may have unexpectedly made a bad choice but are capable of being rehabilitated (Unnever et al., 2010).

Research also suggests that in-group bias may influence causal attributions. That is, individuals are more likely to attribute in-group members' positive behaviors to internal causes, and attribute in-group members' negative behaviors to external factors (Harrison, Howerton, Secarea, \& Nguyen, 2008). Conversely, positive behaviors of out-group members are likely to be attributed to external causes while out-group members' negative behaviors are likely to be attributed to internal factors (Harrison et al., 2008; Pettigrew, 1979). Therefore, it would be expected that women evaluating women (in-group members) criminal suspects would be more likely to attribute the suspect's behavior to external factors (i.e., the situation in which the woman found herself) but attribute the same behavior displayed by men (out-group members) to internal/personal factors (i.e., personal failings or a person's inherent faults). Favorability response biases to in-group members have been shown in a number of studies. For example, Lehmann and Santilli (1996) found that college students in general believed that violence by men was more likely to be the result of negative personality traits whereas violence by women was more likely to be in response to situational events.

It may be a natural tendency to simply assume that in-group members will exhibit a favorability bias towards their own group. Although in-group preference can occur, it generally happens only under certain conditions. The next section will provide an overview of social ident ity theory and the conditions under which in-group preference and out-group discrimination will likely occur.

\section{Social Identity Theory and In-group Preference}

In-group bias is driven by a desire to positively differentiate one's in-group (e.g., women) from relevant out-groups (e.g., men) and by pressure to obtain and maintain a positive and meaningful social identity (Tajfel $\&$ Turner, 1986). Scholars have maintained that people have a natural tendency to favor their own group and sometimes undervalue relevant out-groups to which they do not belong (Bettencourt, Dorr, Charlton, \& Hume, 2001). However, scholars have either not clearly understood, or not articulated, the psychological mechanisms at work that lead people to display an in-group favorability bias.

One significant factor that impacts in-group favoritism is the amount of identification a person has with his/her in-group. Everyone is either voluntarily or involuntarily a member of a number of groups, but membership to each group does not carry the same level of personal significance, value or salience. The extent to which group membership is important to a person will generally determine the degree to which a person will exhibit in-group bias. This is to say that two people may be members of numerous groups but their memberships to only a few groups hold any significance. The more identification and pride people hold for their in-group the more likely they will express in-group favoritism (Lew is \& Sherman, 2010) and negative feelings tow ard relevant out-groups (Vanhoomissen \& Van Overwalle, 2010). 
Research on group identities demonstrates that in-group and out-group social comparisons are based on a specific social identity that is both salient to and valued by the in-group (Hogg, Terry, \& White, 1995). The salience of a distinctive trait determines its accessibility and meaningfulness for group members (Vignoles, Chryssochoou, \& Breakwell, 2000). The greater the salience of the specific social category such as gender (Mastin, Andsager, \& Lee, 2007) the greater one's in-group identification and favoritism (Appiah, 2001). Gender in-group identification is not the same among men and women (Sidanius \& Pratto, 2003). Studies show that women are more highly identif ied with their gender group than men are with their gender group (Iyer \& Ryan, 2009). This is not surprising given Leach and colleagues (2002) found that, relative to lower status groups, members of higher status groups are generally less aware of and identified with their group. This leads to a discussion of the role group status plays on a person's intragroup and intergroup attitudes.

An important factor that impacts in-group favoritism is whether a group has been stigmatized or perceived as a lower-status group. Groups that are often stigmatized may be more likely than infrequently stigmatized groups to protect their self-concept by favoring their own group and by discriminating against out-group members. Tajfel and Turner (1986) maintain that through social comparison, members of a lower status group can recognize their social standing vis-à-vis higher status groups and will be particularly motivated to adopt strategies to achieve a more positive social identity (Bettencourt et al., 2001; Tajfel \& Turner, 1986). Studies indicate that, as a way of compensating for their less favorable societal status, low status groups show greater in-group favoritism than high status groups (Bettencourt et al., 2001). Similar research confirms that low -status groups discriminate against relevant out-groups more than do high-status group members (Appiah, Knobloch-Westerwick, \& Alter, 2013; Bettencourt et al., 2001; Brewer, 1979). In support, a number of studies across a variety of contexts reveal that majority/non-stigmatized group members show no in-group bias whereas minority/stigmatized group members show an in-group favorability bias (e.g., Knobloch-Westerwick, Appiah, \& Alter, 2008). These findings are not surprising given in-group preference and out-group discrimination are more likely to occur when people highly identify with their in-group and the in-group holds significant importance in defining their self-concept (Lewis \& Sherman, 2010; Vanhoomissen \& Van Overwalle, 2010).

Based on these findings it is expected that a similar pattern of results would occur among men (majority/non-stigmatized group) and women (minority/stigmatized group). According to Crocker \& Major (1989), members of stigmatized groups belong to "social categories about which others hold negative attitudes, stereotypes, and beliefs, or which, on average, receive disproportionately poor interpersonal or economic outcomes relative to members of the society at large because of discrimination against members of the social category" (p. 609). Women fit this description primarily as a result of the general lack of social power and privilege they have in comparison to men, and this "lack" has commonly been emphasized via society's gender economic gap.

Historically, men, as the dominant gender, have not had to deal with the negative stigmas, issues of marginalization, and general lack of political, educational, and economic power that women encounter. Consequently, while gender may not be a particularly salient and important characteristic for men, it is reasonably so for women, given their position in society. Often marginalized, stigmatized, and perceived as a minority, women may more strongly identify with and value their membership within their gender group relative to their male counterparts as a result of the additional daily societal and cultural struggles that coincide with being a woman. 
Another particularly important factor that leads to in-group bias is the perceived threat or competition from a relevant out-group. Drawing on social identity theory, when a person believes there is a significant threat to their self-concept, they will respond in a manner that helps maintain a positive identity such as engaging in in-group favoritism or emphasizing or seeking negative information concerning members of relevant out-groups (Lewis \& Sherman, 2010). In the context of domestic abuse, in which the threat to women is not merely over resources, but literally their own lives and well-being, women will be more attuned to the role of the female as the non-aggressor (not guilty of the crime) and will seek out cues and information that portray men in a negative light and conclude that men are more deserving of stiffer sentences than women.

In short, as a traditionally marginalized group, women are often depicted as a stigmatized minor ity group vis-à-vis men who - being less maligned and often in a position of privilege - are seen as a dominant, majority in-group. Thus, in the societal battle for resources, social identity theory will pit men against women in that men, by their mere presence, poses a potential threat to the ability of women to handle and/or control their own status and power. In this study we test the power of social identity with regard to the degree in which women identify with female versus male suspects in domestic abuse cases.

\section{Hypotheses}

Given previous research showing the dichotomy in how women are perceived when committing violent acts compared to men and that men are in a privileged position compared to women, we expect that men will employ chivalry protection strategies. These strategies will lead men to evaluate a female criminal suspect more positively, or no differently, than an equivalent male criminal suspect, regardless of the type of violent criminal act performed by the female. Moreover, we anticipate that women will display in-group favoritism towards female criminal suspects, given women's lower status in society, women's high identification with their gender, and perceived threat/competition with men. In contrast, men are not predicted to exhibit in-group favoritism towards a male suspect because their dominant status in society makes them unlikely to have high in-group identification, view their group as lower in status, or view women as a threat or source of competition. Therefore, the following overarching hypotheses are proposed:

H1: Female participants will display an in-group preference bias such that they will respond more favorably to a female (in-group) criminal suspect than they will a male (out-group) criminal suspect. Specifically, female participants will: a) more likely perceive the crime was justified when it was committed by a woman; b) display more sympathy for a female suspect; c) assign less jail time to a female suspect; d) have more favorable attitudes towards the female suspect; e) have more positive attitudes towards a female victim; f) be less likely to attribute female suspect's behavior to internal factors; and g) more likely attribute a female suspect's behavior to external factors than they will when evaluating a male suspect.

$\mathrm{H} 2$ : Male participants will not display an in-group preference for male criminal suspects.

\section{Method}

\section{Design}

This experiment employed a 2 (participants' gender: male or female) x 2 (gender of criminal suspect: male or female) x 2 (story type: fatal story, non-fatal story) between-subjects factorial design. The seven dependent variables were: 1) perception the crime was justified; 2) sympathy for criminal suspect; 3) assigned jail time; 4) attitude towards the criminal suspect; 5) attitude towards the victim; 6) internal attribution; and 7) external attribution. 


\section{Participants and Procedure}

A total of 937 adult participants from 11 different southern U.S. states completed this study. Participants were recruited using an online Qualtrics panel and were between the ages of 30-82 ( $M=48.19, S D=12.17)$. Outliers were omitted from the data to ensure that the study included only participants who viewed and read the story stimuli. As a result, participants whose total time spent reading the story was more than 2 standard deviations from the mean were removed from the data analysis, leaving a total of 874 participants (62\% female and $38 \%$ male).

Southerners were recruited for this study because they tend to hold more traditional attitudes than people in other U.S. regions (DiMaggio, Evans, \& Bryson, 1996), and such traditions are especially pronounced with regard to gender. According to Hulbert (1989), a conservative attitude toward women is a distinguishing trait of Southern culture, one that is centered on the figure of the Southern belle who is defined by physical weakness, male dependency, and domesticity (Conlee, 2012).

An effort was made to include a diverse sample regionally, racially, and educationally. Participants were recruited from the following southern states: Alabama $(N=79)$, Arkansas $(N=51)$, Florida $(N=121)$, Georgia $(N=135)$, Kentucky $(N=58)$, Louisiana $(N=69)$, Mississippi $(N=60)$, North Carolina $(N=22)$, South Carolina $(N=86)$, Tennessee $(N=75)$, and Texas $(N=118)$. An effort was made to have a racial diverse sample. The majority of respondents identified as white (50.8\%), and 49.2\% identified as Black or African American.

The majority of participants had completed some (28.7\%) or all (31.4\%) of a college or university degree, 9.6\% of participants completed a Graduate degree, $19.6 \%$ had only a high school degree, $7.8 \%$ attended trade or vocational school, and only $3.0 \%$ had less than a high school degree.

In an online survey, participants were randomly assigned to read one of 12 mock newspaper articles before completing a questionnaire: Richard Smith (white male photo $N=72$, black male photo $N=68$, no photo $N=$ 62), Angela Smith (white female photo $N=66$, black female photo $N=68$, no photo $N=75$ ), Robert Jones, (white female photo $N=75$, black female photo $N=87$, no photo $N=74$ ), Diane Jones (white female photo $N$ $=76$, black female photo $N=73$, no photo $N=78$ ). They spent an average of $M=125.79$ seconds reading the stories $(S D=64.35)$. The news stories that featured Richard Smith and Angela Smith discussed a case of domestic abuse that led to the victim being killed (fatal condition). The news stories that featured Robert Jones and Diane Jones discussed a domestic abuse case that did not lead to the victim being killed (non-fatal condition).

\section{Stimulus Material}

The stimulus consisted of real news stories that were edited to remove the real names and cities. Printed versions of professionally created online news stories were used. Each story was approximately the same length and made no mention of race or ethnicity. In the real world, readers of news stories are likely to come across several stories in one reading session, some with pictures and some without pictures, some stories with pictures featuring blacks, some stories with pictures of whites, some stories with men and some stories that feature women. Thus, it was important to create a natural and realistic reading experience whereby each participant was exposed to multiple pictorial story conditions during the same reading session.

Twelve newspaper articles were used for this study andwere all written by a former professional journalist to read like an actual news account. All of the stories were designed to appear as if they were from an online 
news source called The Daily Tribune and featured a story about a crime involving an individual and his/her spouse. There were two story type conditions - fatal and non-fatal. The first set of articles featured a story about an individual fatally stabbing his/her spouse after a suspected affair (fatal condition). This story details the history of domestic violence in the relationship whereby police had been called to the couple's home on a number of occasions. After a long and heated altercation at 3:00 am, which included obscenities, accusations of cheating, and physical threats from both parties, the stabbing occurred. The suspect in the article faces murder charges but claims the actions were a result of self-defense. The second set of articles featured a story about an individual using a gun to fire a warning shot at an abusive spouse during an argument and physical confrontation (non-fatal condition). In the article the suspect claims being cornered in a garage, grabbing a gun kept in the garage, and only firing a warning shot to ward off the spouse after the spouse threatened to kill him/her. Despite claiming self-defense, the suspect is being charged with attempted murder.

Three of the fatal stabbing stories discussed women stabbing their husbands and three discussed men stabbing their wives. Of the warning shot stories, three featured a female suspect firing at her husband and three featured a male suspect firing at his wife. Each of these conditions (male fatal stabbing, female fatal stabbing, male warning shot, female warning shot) had three additional conditions where the photo accompanying the article was varied to include: a white suspect, a black suspect, or no photo of the suspect. In an effort to ensure consistency, the same photos were used across conditions (e.g., the white female photo in the fatal stabbing condition was the same as the photo in the white female warning shot condition). Since race is often associated with violence and crime, it was important for the study to include evaluations from participants who were black and white about criminal suspects who were black and white. Some scholars have argued that the color of crime is often associated with blacks, and the authors wanted to rule out race as a significant contributing factor. No significant differences were found based on the race of the suspect pictured alongside the new s story.

\section{Measures}

Justification was measured using 1 item asking "How justified was SUSPECT in stabbing his/her SPOUSE?" ( 1 = not at all justified to $7=$ completely justified; $M=3.73, S D=2.01)$. For each of the dependent variables the actual name of the "suspect" and "victim" were used in the questions (e.g., Robert Jones, Diane Jones).

Sympathy Towards the Suspect was measured using 3 items adapted from Batson, Fultz, and Schoenrade (1987). Items included: "To what extent do you feel sympathetic for SUSPECT", "To what extent do you feel compassionate for SUSPECT", and "To what extent do you feel sorry for SUSPECT" $(1=$ not at all, 7 = completely; $M=4.35, S D=1.82, \alpha=0.94$ ).

Attitude Towards the Suspect and Attitude Towards the Victim were measured using 11 semantic differential items as modeled in Appiah (2002), Devine and Elliot (1995), and Peffley, Hurwitz and Sniderman (1997). The following pairs were used: lazy/hardworking, unreliable/dependable, undisciplined/disciplined, violent/peaceful, unintelligent/intelligent, poor/rich, immoral/moral, unsuccessful/successful, untidy/neat, naïve/sophisticated, criminal/law-abiding (Attitude Tow ards Suspect: $M=3.75, S D=1.11, \alpha=0.93$; Attitude Towards Victim: $M=3.29, S D=1.10, \alpha=0.94)$.

Internal and External Attribution was measured using a 6-item scale, modeled after Templeton and Hartnagel (2012). Three of the items measured Internal Attribution, and three items measured External Attribution. This scale was used to ascertain the extent to which a participant attributes responsibility for events 
to internal (personal) factors or to external (situational) factors. Sample items included, "SUSPECT's social circumstances may deserve part of the blame for the CRIME", and "A major cause of SUSPECT's behavior can be attributed to his/her personal or individual failings" $(1=$ strongly disagree, $7=$ strongly agree; Internal Attribution $M=3.98, S D=1.31, \alpha=0.64$; External Attribution $M=4.01, S D=1.38, \alpha=0.59$ ).

Jail Time was measured using 1 item asking "If SUSPECT is found guilty of a crime, what would you consider an appropriate sentence for him/her?" (Rye, Greatrix, \& Enright, 2006). Participants were asked to choose from 11 options ranging from "no jail time" to "the death penalty", $M=4.52$ (4= "1-2 Years in Prison", $5=$ "3-5 Years in Prison"), $S D=2.92$.

\section{Results}

The results of the experiment are presented and discussed according to the hypotheses presented earlier. It was expected that female participants would display an in-group preference bias such that they would respond more favorably to a female criminal suspect than they would a male criminal suspect. In contrast, male participants would not display an in-group preference for male criminal suspects vis-à-vis female criminal suspects. A series of three-way analyses of variance were conducted to evaluate the effects of participants' gender (i.e., male or female), gender of criminal suspect (i.e., male or female), and story type (i.e., fatal or non-fatal) on participants' responses to the stories about criminal suspects. Only significant two- or three-way interactions are mentioned in the results. These same analyses are conducted for each dependent variable.

\section{Perceived Justification of Crime}

It was hypothesized that female participants would display an in-group bias such that they are more likely to believe the crime was justified when the crime was committed by a female in-group member than by a male out-group member. No in-group preference was expected for male participants. There was a three-way interaction among partic ipants' gender, gender of the suspect, and story type $(F(1,873)=18.99, p<0.001)$, and post hoc analyses were conducted to examine this interaction.

For women, a two-way ANOVA was conducted that indicated main effects for suspect gender $(F(1,544)$ $=162.91, p<0.001)$ and story type $(F(1,544)=4.01, p<0.05)$. The main effect for suspect's gender shows that women displayed an in-group favorability bias for criminal suspects (see Appendix Figure A1). Specific ally, women were more likely to believe that the criminal suspect was justified in committing the crime when the suspect was a woman $(M=4.63)$ than when the criminal suspect was a man $(M=3.01)$. The story type main effect indicates that women were more likely to believe the crime was justified after reading the non-fatal story condition $(M=3.83)$ than they were after reading the fatal crime story $(M=3.52)$. However, these main effects were qualified by a two-way interaction $(F(1,544)=9.64, p<0.01)$. Closer examination of the means demonstrates that women were more likely to see the crime as justified when the criminal suspect was an in-group member than when the suspect was an out-group member, but this was more pronounced after they read the non-fatal story $(M=5.03)$ compared to the fatal story $(M=4.26, p<0.001$, Appendix Figure A2). These findings support the hypothesis that female participants would display an in-group favorability bias.

For men, a two-way ANOVA was conducted and revealed a main effect for gender $(F(1,329)=70.49, p<$ 0.001). This main effect shows that men had an out-group favorability bias (see Appendix Figure A1). That is, men believed that the crime was more justified when the criminal suspect was female $(M=4.66)$ than when the criminal suspect was male $(M=2.89)$. This main effect was qualified by a two-way interaction $(F(1,329)=$ 9.81, $p<0.01)$. Post hoc analyses indicated that male participants were more likely to believe the crime was 
justified after reading the non-fatal story condition $(M=4.96)$ compared to the fatal story condition $(M=4.40$, $p<0.01$ ), but this was only true when the suspects were out-group members (see Appendix Figure A3). When the criminal suspect was male, male participants were more likely to believe the crime was more justified after reading the fatal story condition $(M=3.34)$ than after reading the story in which a non-fatal crime had occurred $(M=2.65, p<0.001)$. These findings support the hypothesis that male participants would not display an in-group gender bias for criminal suspects.

\section{Sympathy for Criminal Suspect}

It was hypothesized that female participants would display an in-group preference in that they would have more sympathy for female suspects than they would for male suspects. No in-group preference was expected for male participants. The ANOVA indicated main effects for the story condition $(F(1,873)=10.60, p<0.001)$ and gender of the criminal suspect $(F(1,873)=26.66, p<0.001)$. This indicates that all participants demonstrated more sympathy for a criminal suspect after reading the non-fatal story $(M=4.52)$ than they did after reading the fatal story condition $(M=4.15, p<0.001)$. Moreover, the main effects showed that participants displayed more sympathy tow ards a criminal suspect that was an in-group member $(M=4.63)$ than they did tow ards a criminal suspect who was an out-group member $(M=4.05, p<0.001)$.

However, these findings were qualified by a two-way interaction between participants' gender and gender of the suspect $(F(1,873)=127.33, p<0.001)$. Post hoc analyses indicate that women displayed more sympathy for criminal suspect that was an in-group member $(M=5.31)$ than they did for a criminal suspect who was an out-group member $(M=3.43, p<0.001)$. For male participants, an ANOVA indicated that they were more sympathetic towards women out-group members $(M=4.67, S D=1.56)$ than they were male in-group members $(M=3.93, S D=1.82, p<0.001$, see Appendix Figure A4). These findings support the hypotheses.

\section{Assigned Jail Time}

It was hypothesized that female participants would assign less jail time to in-group members than they would to out-group members. No in-group preference was expected for male participants. The analysis indicated main effects for the story condition $(F(1,873)=203.10, p<0.001)$ and gender of the criminal suspect $(F(1,873)=10.77, p<0.001)$. This indicates that all participants were more likely to assign more jail time to a criminal suspect in the fatal story condition $(M=5.68)$ than they were to the criminal suspect in the non-fatal story condition $(M=3.22)$. Moreover, the main effects showed that participants were more likely to assign greater jail time to a criminal suspect that was an out-group member $(M=4.73)$ than they were to a criminal suspect that was an in-group member $(M=4.17)$.

However, these findings were qualified by a two-way interaction between participants' gender and the gender of the criminal suspect in the story $(F(1,873)=534.02, p<0.001)$. Post hoc analyses using ANOVA demonstrated that women readers assigned less jail time to in-group female suspects $(M=3.34)$ than they did to out-group male suspects $(M=5.65, p<0.001)$. In contrast, male readers assigned less jail time to out-group female suspects $(M=4.04)$ than they did to in-group male suspects $(M=5.08, p<0.001$, see Appendix Figure A5). These findings support the hypotheses.

\section{Attitude Towards the Suspect}

It was expected that female participants would display an in-group preference such that they would have more positive attitudes towards a criminal suspect that was an in-group member than they would a criminal 
suspect that was an out-group member. The analysis indicated a main effect for gender of the suspect $(F(1,873)$ $=7.12, p<0.01)$. This main effect indicates that all participants had more positive attitude tow ards a criminal suspect who was an in-group member $(M=3.83)$ than they did for a criminal suspect who was an out-group member $(M=3.63, p<0.01)$. However, this main effect $w$ as qualified by a three-way interaction among story condition, gender of the criminal suspect, and participants' gender $(F(1,873)=7.80, p<0.01)$. Post hoc analyses were conducted to examine this interaction.

An ANOVA was conducted for female participants, which indicated main effects for story type $(F(1,544)$ $=4.07, p<0.05)$ and gender of criminal suspect $(F(1,544)=67.13, p<0.01)$. The suspect gender main effect indicates that female readers had more positive attitude towards in-group female suspects $(M=4.14)$ than they did for out-group male suspects $(M=3.41, p<0.05$, see Appendix Figure A6). The story type main effect indicates that women readers had more positive attitudes tow ards the criminal suspects featured in the non-fatal stories $(M=3.86)$ than they did the fatal stories $(M=3.68, p<0.05)$. These main effects were qualified by a two-way interaction between suspect gender and story type $(F(1,544)=8.79, p<0.01)$. Closer examination of the means demonstrate that female participants had more positive attitudes towards an in-group female suspect than an out-group male suspect, but this effect was more pronounced when participants read the non-fatal story $(M=4.33)$ than it was when participants read the fatal story $(M=3.94, p<0.05$, Appendix Figure A7).

For men, an ANOVA was conducted to examine the means. There was a main effect for suspect gender $(F(1,329)=8.79, p<0.01)$, which demonstrates that male readers had more positive attitudes towards out-group female suspects $(M=3.89)$ than they did towards in-group male suspects $(M=3.53$, see Appendix Figure A6). These findings support the hypotheses.

\section{Attitude Towards the Victim}

The analysis indicated no significant findings. The results did not support the hypothesis that female participants would display an in-group preference whereby they would have more positive attitudes towards a female victim compared to a male victim.

\section{Internal Attribution}

It was hypothesized that female participants would display an in-group preference such that they would be less likely to attribute the suspect's criminal behavior to internal or personal factors when the suspect was a female compared to a male. In contrast, it was expected that male participants would display no in-group favoritism. The analysis indicated a main effect for gender of the suspect $(F(1,873)=4.30, p<0.05)$. This main effect indicates that all participants were more likely to attribute the criminal suspect's behavior to internal, personal factors when the criminal suspect was an out-group member $(M=3.83)$ than when the criminal suspect was an in-group member $(M=4.15)$. However, this main effect was qualified by a signif icant three-way interaction among story condition, gender of the criminal suspect, and participants' gender $(F(1,873)$ $=15.17, p<0.01$ ). Post hoc analyses were conducted to examine this interaction.

A two-way ANOVA was conducted for female participants, which indicated main effects for story type $(F(1,544)=5.05, p<0.05)$ and gender of the criminal suspect $(F(1,544)=35.40, p<0.001)$. The story type main effect indicated that female participants were more likely to attribute the criminal suspect's behavior to internal, personal factors after reading the story in which a fatal crime occurred $(M=4.05)$ than they were after reading the story with the non-fatal crime $(M=3.80)$. Similarly, female participants were more likely to attribute the criminal suspect's behavior to internal, personal factors when the suspect was a male out-group 
member $(M=4.25)$ compared to when the suspect was a female in-group member $(M=3.60)$. However, these main effects were qualified by a two-way interaction $(F(1,544)=7.47, p<0.05)$. Closer examination of the means demonstrate that women were less likely to attribute the criminal suspect's behavior to internal, personal characteristics when the criminal suspect was female but this was more pronounced after they read the non-fatal story condition $(M=3.35)$ compared to the fatal story condition $(M=3.85, p<0.05$, see Appendix Figure A8). These findings support the hypothesis that female participants would display an in-group favorability bias.

A two-way ANOVA was conducted for male participants, which indicated a main effect for gender of criminal suspect $(F(1,329)=4.12, p<0.05)$. The criminal suspect gender main effect indicated that male participants were more likely to attribute the behavior by the criminal suspect to internal, personal factors when the criminal suspect was male $(M=4.21)$ compared to when the criminal suspect was female $(M=3.91)$. However, this main effect was qualified by a two-way interaction $(F(1,329)=4.82, p<0.05)$. Closer examination of the interaction demonstrate male participants were more likely to attribute criminal behavior to internal factors when the suspect was an in-group member compared to when the suspect was an out-group member but only in the non-fatal $(M=4.37$ vs. $M=3.75, p<0.001)$ vis-à-vis the fatal story condition $(M=$ 4.06 vs. $M=4.06$, see Appendix Figure A9). These findings support the hypothesis that male participants would not display an in-group bias.

\section{External Attribution}

It was hypothesized that female participants would display an in-group preference such that they would be more likely to attribute the suspect's criminal behavior to external or situational factors when the suspect was an in-group member compared to when the suspect is an out-group member. In contrast, it was expected that male participants would display no in-group preference.

The analysis indicated a two-way interaction between gender of the criminal suspect and participants' gender $(F(1,873)=62.04, p<0.01)$. Post hoc analyses were conducted to examine this interaction. An ANOVA was conducted for female participants, which indicated female participants were more likely to attribute the behavior by the criminal suspect to external situational factors when the suspect was an in-group member $(M=4.39)$ compared to when the suspect was an out-group member $(M=3.57, p<0.001$, see Appendix Figure A10). These findings support the hypothesis that female participants would display in-group favoritism.

An ANOVA was conducted for male participants, which indicated male participants were more likely to attribute the behavior by the criminal suspect to external situational factors when the criminal suspect was an out-group member $(M=4.39)$ compared to when the criminal suspect was an in-group member $(M=3.75, p<$ 0.001). These findings support the hypothesis that male participants would not display in-group favoritism.

\section{Discussion}

A major aim of this study was to test the merits of both the chivalry hypothesis and social identity theory. The chivalry hypothesis posits that leniency or preferential treatment is given to women as long as they adhere to traditional gender roles (Koons-Witt et al., 2014). This perspective implies that men would be more lenient on women as they are perceived as being less culpable than men. In contrast, social identity theory suggests that men, because of in-group members' natural tendency to favor their own group over out-groups, would actually respond more harshly to women criminal suspects than they would to male suspects. However, previous research using social identity theory has often failed to identify under what conditions in-group members are 
likely to display in-group favoritism. The factors that are likely to lead in-group members to display in-group favoritism include the importance of in-group membership, the perceived threat from out-group members, and being considered a lower status or stigmatized group. Given that women fit these categories more than men, it was expected that women would display in-group favoritism but men would not.

This study found evidence that showed the public's desire to judge female criminal suspects more favorably and leniently than male suspects. As expected, the findings clearly demonstrated that women have a greater tendency to be biased in favor of their own group than do men. Across the board women showed in-group favoritism tow ards criminal suspects that matched their own gender. In contrast, men did not show a preference for their own gender in any context. In fact, the findings demonstrate the opposite. Specifically, the findings indicate that both men and women participants were more likely to believe the crime was justified, but they also have more sympathy for the criminal suspect, assign less jail time, and have more positive attitudes towards the suspect when the criminal suspect was female rather than male. Moreover, male and female participants alike made internal attributions about the criminal behavior of the male suspects but external attributions for the criminal behavior of the female suspects. These findings were more pronounced when the nature of the crime led to the victim surviving (non-fatal) compared to when the victim was killed (fatal).

Despite the severe violence and heinous nature of these criminal acts, in-group favoritism seems to supersede objectivity in women's (and men's) perception of female criminal suspects, and perhaps adherence to stereotypical beliefs that women are docile, non-violent, gentle and caring, might override men's evaluation of women in criminal cases, based on our findings. Although society labels certain acts criminal and worthy of punishment, it also seems to excuse certain actors of criminal behavior especially when they can demonstrate some partial justification for the behavior (Coffey, 1993). Perhaps one limitation of this study is that in the news stories the suspect claimed the use of self-defense to justify the alleged criminal act. This claim may have cued or more readily activated gender stereotypes that associate female suspects as frail and in need of protection while male victims may have been characterized as violent aggressors, genetically predisposed towards criminal acts. Future research should examine whether these same chivalry-like responses are evident in first-degree premeditated murder cases, or other serious crimes in which it is clear that the female (and male) suspect acted ruthlessly and without justification. Perhaps crimes of passion, rage or jealousy - that might be more associated with women than men-might also evoke different characterizations of the suspects from women than men. However, despite these limitations, even when committing identical egregious crimes, it appears that both women and men perceive women differently, and largely on gender-based stereotypical lines.

\section{References}

Albonetti, C. A. (2011). Judicial discretion in federal sentencing: An intersection of policy priorities and law. Criminology \& Public Policy, 10(4), 1151-1155.

Appiah, O. (2001). Ethnic identification on adolescents' evaluation of advertisements. Journal of Advertising Research, 41(5), 7-22.

Appiah, O. (2002). Black \& White viewers' perception \& recall of occupational characters on television. Journal of Communication, 52(4), 776-793.

Appiah, O., Knobloch-Westerwick, S., \& Alter, S. (2013). Ingroup favoritism and outgroup derogation: Effects of news valence, character race, and recipient race on selective news reading. Journal of Communication, 63(3), 517-534.

Bargh, J. A. (1996). Automaticity in social psychology. In E. T. Higgins \& A. W. Kruglanski (Eds.), Social psychology: Handbook of basic principles (pp. 169-183). New York: Guilford Press. 
Barnett, O. W., Lee, C. Y., \& Thelen, R. E. (1997). Gender differences in attributions of self-defense and control in interpartner aggression. Violence Against Women, 3(5), 362-481.

Batson, C. D., Fultz, J., \& Schoenrade, P. A. (1987). Adults' emotional reactions to the distress of others. Empathy and Its Development (pp. 163-184).

Belknap, J. (2007). The invisible woman: Gender, crime, and justice (3rd ed.). Belmont, CA: Thomson Wadsworth Publishing Company.

Berrington, E., \& Honkatukia, P. (2010). An evil monster and a poor thing: Female violence in the media. Journal of Scandinavian Studies in Criminology and Crime Prevention, 3(1), 50-72.

Bettencourt, B. A., Dill, K. E., Greathouse, S. A., Charlton, K., \& Mulholland, A. (1997). Evaluations of ingroup and outgroup members: The role of category-based expectancy violation. Journal of Experimental Social Psychology, 33(3), $244-275$.

Bettencourt, B. A., Dorr, N., Charlton, K., \& Hume, D. L. (2001). Status differences and in-group bias: A meta-analytic examination of the effects of status stability, status legitimacy, and group permeability. Psychological Bulletin, 127(4), 520-542.

Bickle, G. S., \& Peterson, R. D. (1991). The impact on gender-based family roles on criminal sentencing. Social Problems, 38, 372-394.

Biernat, M., Vescio, T. K., \& Billings, L. S. (1999). Black sheep and expectancy violation: Integrating two models of social judgment. European Journal of Social Psychology, 29, 523-542.

Branscombe, N. R., \& Owen, S. (1991). Influence of gun ownership on social inferences about women and men. Journal of Applied Social Psychology, 21(19), 1567-1589.

Brennan, P. K., \& Vandenberg, A. L. (2009). Depictions of female offenders in front-page newspaper stories: The importance of race/ethnicity. International Journal of Social Inquiry, 2(2), 141-175.

Campbell, A. (1993). Men, women, and aggression. New York, NY: Basic Books.

Coffey, M.P. (1993). The genetic defense: Excuse or explanation? William \& Mary Law Review, 35(1), 353-399.

Conlee, D. (2012). Gender roles in organizations in the Southeastern United States (Masters Thesis). Gonzaga University, Spokane, WA.

Crew, K. B. (1991). Sex differences in criminal sentencing: Chivalry or patriarchy? Justice Quarterly, 8, 59-83.

Crocker, J., \& Major, B. (1989). Social stigma and self-esteem: The self-protective properties of stigmas. Psychological Review, 96(4), 608-630.

Daly, K., \& Bordt, R. (1995). Sex effects and sentencing: A review of the statistical literature. Justice Quarterly, 12, $143-177$.

Daly, K., \& Tonry, M. (1997). Gender, race, and sentencing. Crime and Justice, 22, 201-252.

Devine, P. G. (1989). Stereotypes and prejudice: Their automatic and controlled components. Journal of Personality and Social Psychology, 56(1), 5-18.

Devine, P. G., \& Elliot, A. J. (1995). Are racial stereotypes really fading? The Princeton trilogy revisited. Personality and Social Psychology Bulletin, 21, 1139-1150.

DeWees, M. A., \& Parker, K. F. (2003). Women, region, and types of homicide: Are there regional differences in the structural status of women and homicideoffending? Homicide Studies, 7(4), 368-93.

DiMaggio, P., Evans, J., \& Bryson, B. (1996). Have American's social attitudes become more polarized? American Journal of Sociology, 102(3), 690-755.

Dixon, T. L., \& Linz, D. (2000). Overrepresentation and underrepresentation of African Americans and Latinos as lawbreakers on television news. Journal of Communication, 50(2), 131-154.

Dunn, M. A. (1993). Understanding women's responses to domestic violence: A redefinition of battered woman syndrome. Hofstra Law Review, 21(4), 1193-1242.

Elgot, J. (2014). Women get a rougher deal when they commit crime. Retrieved from http://www.huffingtonpost.co.uk/2014/01/29/women-crime-vicky-pryce_n_4685494.html

Franklin, C. A., \& Fearn, N. E. (2008). Gender, race, and formal court decision-making outcomes: Chivalry/Paternalism, conflict theory or gender conflict? Journal of Criminal Justice, 36, 279-290.

Gauthier, D. K., \& Bankson, W. B. (2004). Who kills whom revisited. Homicide Studies, 8(2), 96-122.

Gilbert, P. R. (2002). Discourses of female violence and societal gender stereotypes. Violence Against Women, 8(11), 1271-1300.

Grabe, M. E., Trager, K. D., Lear, M., \& Rauch, J. (2006). Gender in crime news: A case study test of the chivalry hypothesis. Mass Communication and Society, 9(2), 137-163. 
Grasmick, H. G., \& McGill, A. L. (1994). Religion, attribution style, and punitiveness toward juvenile offenders. Criminology, $32(1), 23-46$.

Hackett, L., Day, A., \& Mohr, P. (2008). Expectancy violation and perceptions of rape victim credibility. Legal \& Criminological Psychology, 13(2), 323-334.

Harrison, L. A., Howerton, D. M., Secarea, A. M., \& Nguyen, C. Q. (2008). Effects of in group bias and gender role violations on acquaintance rape attributions. Sex Roles, 59, 713-725.

Heider, F. (1958). The psychology of interpersonal relations. New York: Wiley.

Hogg, M., Terry, D., \& White, K. (1995). A tale of two theories: A critical comparison of identity theory with social identity theory. Social Psychology Quarterly, 58, 255-269.

Hulbert, J. S. (1989). The southern region: A test of the hypothesis of cultural distinctiveness. The Sociological Quarterly, 30(2), 245-266.

Iyer, A., \& Ryan, M. K. (2009). Why do men and women challenge gender discrimination in the workplace? The role of group status and in-group identification in predicting pathway s to collective action. Journal of Social Issues, 65(4), 791-814.

Jan, J. M. (2006). On learning to be assertive: Women and public discourse. Multilingua, 25(1-2), 43-58.

Knight, G. P., Guthrie, I. K., Page, M. C., \& Fabes, R. A. (2002). Emotional arousal and gender differences in aggression: A meta-analy sis. Aggressive Behavior, 28(5), 366-393.

Knobloch-Westerwick, S., Appiah, O., \& Alter, S. (2008). News selection patterns as a function of race: The discerning minority and the indiscriminating majority. Media Psychology, 11(3), 400-417.

Koons-Witt, B. A. (2002). The effect of gender on the decision to incarcerate before and after the introduction of mandatory sentencing guidelines. Criminology, 40(2), 297-328.

Koons-Witt, B. A., Sevigny, E. L., Burrow, J. D., \& Hester, R. (2014). Gender and sentencing outcomes in South Carolina: Examining the interactions with race, age, and offense type. Criminal Justice Policy Review, 25(3), 299-324.

Leach, C. W., Snider, N., \& Iyer, A. (2002). Poisoning the consciences of the fortunate: The experience of relative advantage and support for social equality. In I. Walker \& H. J. Smith (Eds.), Relative deprivation: Specification, development, integration (pp. 136-163). New York: Cambridge University Press.

Lehmann, M., \& Santilli, N. R. (1996). Sex differences in perceptions of spousal abuse. Journal of Social Behavior and Personality, 11(5), 229-238.

Lewis, A. C., \& Sherman, S. J. (2010). Perceived entitativity and the black-sheep effect: When will we denigrate negative ingroup members? Journals of Social Psychology, 150(2), 211-225.

Lowry, D. T., Nio, T. C., \& Leitner, D. W. (2003). Setting the public fear agenda: A longitudinal analy sis of network TV crime reporting, public perceptions of crime, and FBI crime statistics. Journal of Communication, 53(1), 61-73.

Mastin, T., Andsager, J. L., Choi, J., \& Lee, K. (2007). Health disparities and direct-to-consumer prescription drug advertising: A content analy sis of target magazine genres, 1992-2002. Health Communication, 22(1), 49-58.

May, H. (1999). Who killed whom?: Victimization and culpability in the social construction of murder. British Journal of Sociology, 50(3), 489-506.

Messing, J. T., \& Heeren, J. H. (2004). Another side of multiple murder: Women killers in the domestic context. Homicide Studies, 8(2), 123-158.

Moulds, E. F. (1980). Chivalry and paternalism: Disparities of treatment in the criminal justice system. In S. K. Datesman \& F. R. Scarpitti (Eds.), Women, Crime, and Justice. New York: Oxford University Press.

Naylor, B. (2001). Reporting violence in the British print media: Gendered stories. The Howard Journal of Crime and Justice, 40(2), 180-194.

Nooruddin, I. (2007). Blind justice: Seeing race and gender in cases of violent crime. Politics \& Gender, 3, 321-348.

Paape, V. (1998). Confounding the stereoty pes. Horizons, 12(1), 31.

Peffley, M., Hurwitz, J., \& Sniderman, P. M. (1997). Racial stereotypes and whites' political views of blacks in the context of welfare and crime. American Journal of Political Science (pp. 30-60).

Pettigrew, T. F. (1979). The ultimate attribution error: Extending Allport's cognitive analy sis of prejudice. Personality and Social Psychology Bulletin, 5, 461-476.

Phinney, J. S. (1992). The multigroup ethnic identity measure: A new scale for use with diverse groups. Journal of Adolescent Research, 7(2), 156-176.

Pollak, O. (1950). The criminology of women. Philadelphia: University of Pennsylvania Press. 
Rennison, C. M. (2003). Intimate partner violence 1993-2001. Retrieved from http://www.bjs.gov/index.cfm?ty=pbdetail\&iid=1001

Rhymes, E. (2014). Woman as aggressor: The unspoken truth of domestic violence. Retrieved from http://www.mintpressnews.com/woman-aggressor-unspoken-truth-domestic-violence/196746/

Robertson, K., \& Murachver, T. (2009). Attitudes and attributions associated with female and male partner violence. Journal of Applied Social Psychology, 39(7), 1481-1512.

Romer, D., Jamieson, K. H., \& Aday, S. (2003). Television news and the cultivation of fear of crime. Journal of Communication, 53(1), 88-104.

Rye, B. J., Greatrix, S. A., \& Enright, C. S. (2006). The case of the guilty victim: The effects of gender of victim and gender of perpetrator on attributions of blame and responsibility. Sex Roles, 54(9-10), 639-649.

Sassenberg, K., \& Moskowitz, G. B. (2005). Don't stereotype, think different! Overcomingautomatic stereotype activation by mindset priming. Journal of Experimental SocialPsychology, 41, 506-514.

Sidanius, J., \& Pratto, F. (2003). Social dominance theory and the dynamics of inequality: A reply to Schmitt, Branscombe, \& Kappen and Wilson \& Liu. British Journal of Social Psychology, 42, 207-213.

Smart, C. (1977). Women, crime and criminology: A feminist critique. London: Routledge \& Kegan Paul.

Steffensmeier, D., Kramer, J., \& Streifel, C. (1993). Gender and imprisonment decisions. Criminology, 31(3), 411-446.

Swatt, M. L., \& NI, H. (2006). Exploring the difference between male and female intimate partner homicides: Revisiting the concept of situated transactions. Homicide Studies, 10(4), 279-92.

Tajfel, H., \& Turner, J. C. (1986). The social identity theory of intergroup behavior. In S. Worchel \& W. G. Austin (Eds.), Psychology of Intergroup Relations (pp. 7-24). Chicago, IL: Nelson-Hall.

Tamborini, R., Mastro, D. E., Chory-Assad, R. M., \& Huang, R. (2000). The color of crime and the court: A content analysis of minority representation on television. Journalism \& Mass Communication Quarterly, 77(3), 639-653.

Templeton, L. J., \& Hartnagel, T. F. (2012). Causal attributions of crime and the public's sentencing goals. Canadian Journal of Criminology and Criminal Justice, 54(1), 45-65.

Unnever, J. D., Cochran, J. K., Cullen, F. T., \& Applegate, B. K. (2010). The pragmatic American: Attributions of crime and the hydraulic relation hy pothesis. Justice Quarterly, 27(3), 431-457.

Vanhoomissen, T., \& Van Overwalle, F. (2010). Me or not me as source of ingroup favoritismand outgroup derogation: A connectionist perspective. Social Cognition, 28(1), 84-109.

Vignoles, V., Chryssochoou, X., \& Breakwell, G. M. (2000). The distinctiveness principle: Identity, meaning, and bounds of cultural relativity. Personality and Social Psychology Review, 4(4), 337-354.

Young, V. D. (1986). Gender expectations and their impact on black female offenders and victims. Justice Quarterly, 3(3), 305-327. 
Appendix A

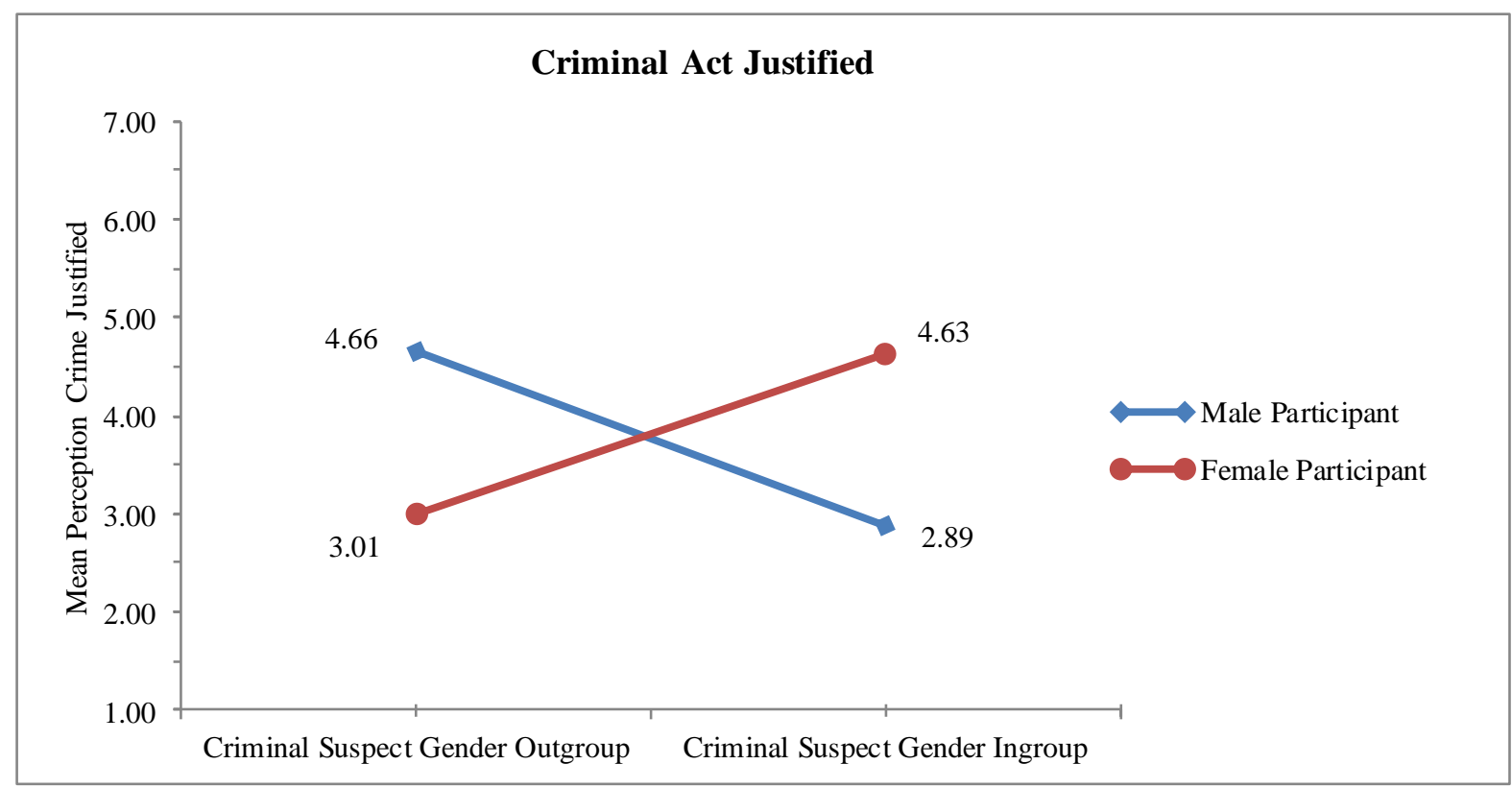

Figure A1. Participants' perception of justification of Criminal Act.

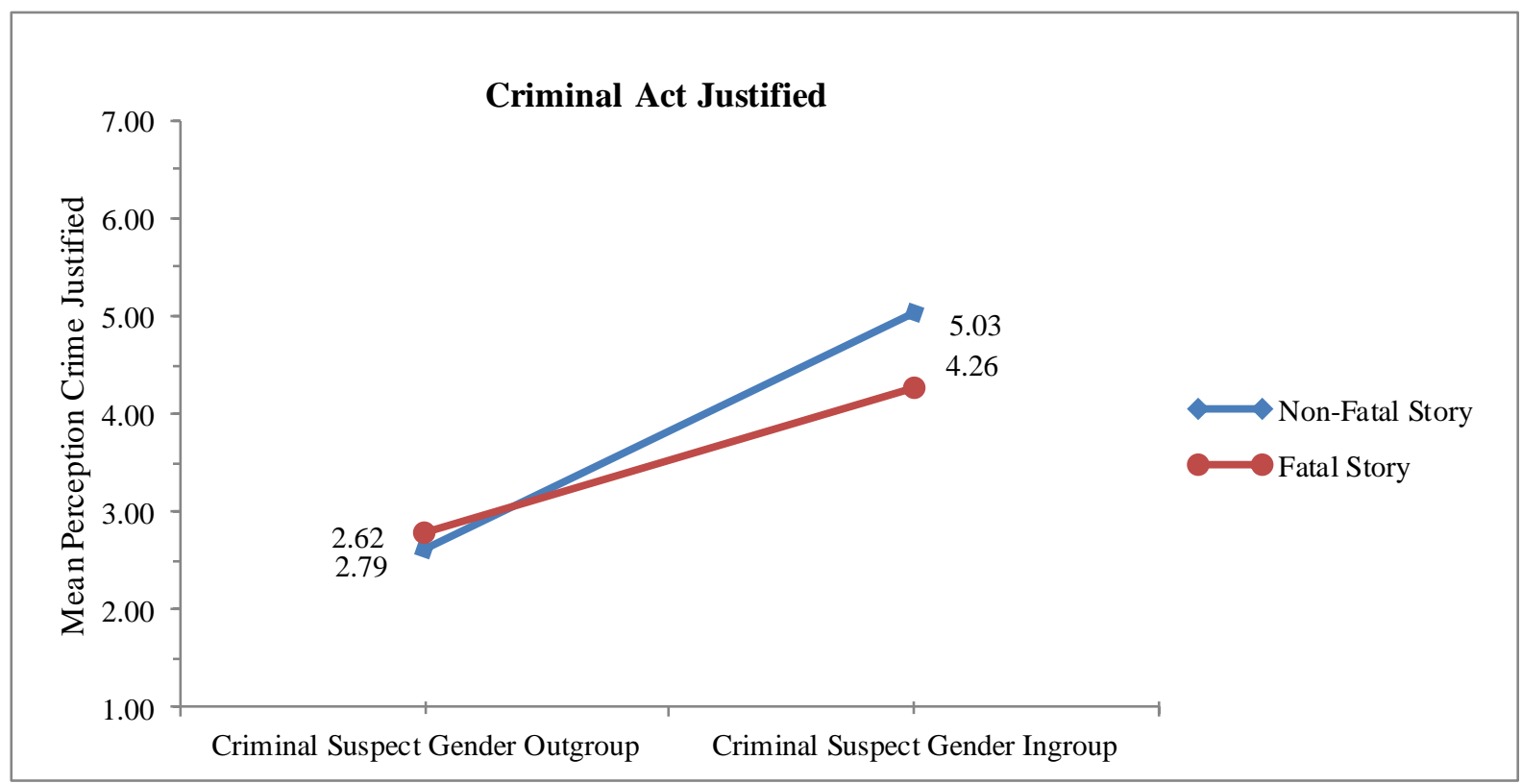

Figure A2. Female participants' perception of justification of Criminal Act based on story condition. 


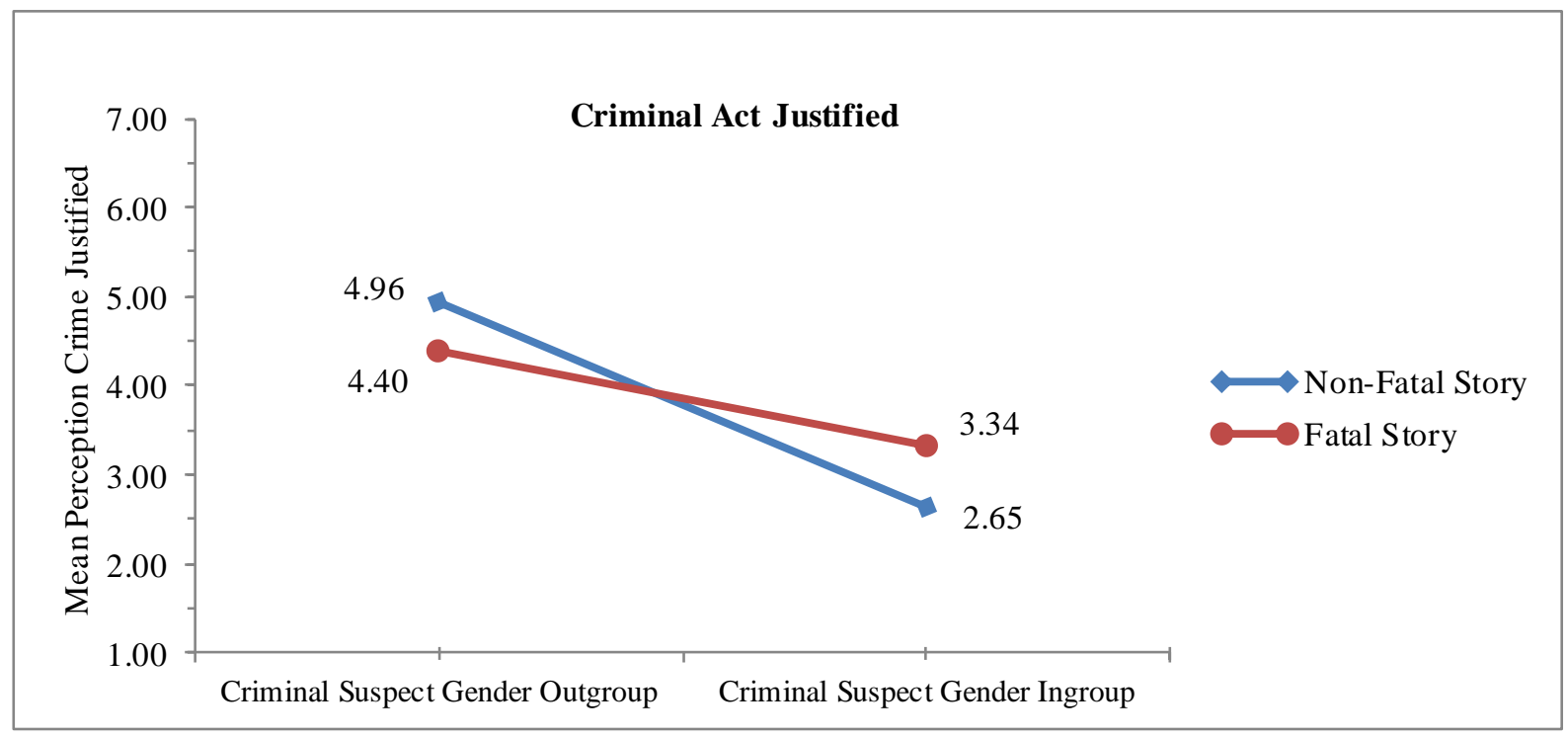

Figure A3. Male participants' perception of justification of Criminal Act based on story condition.

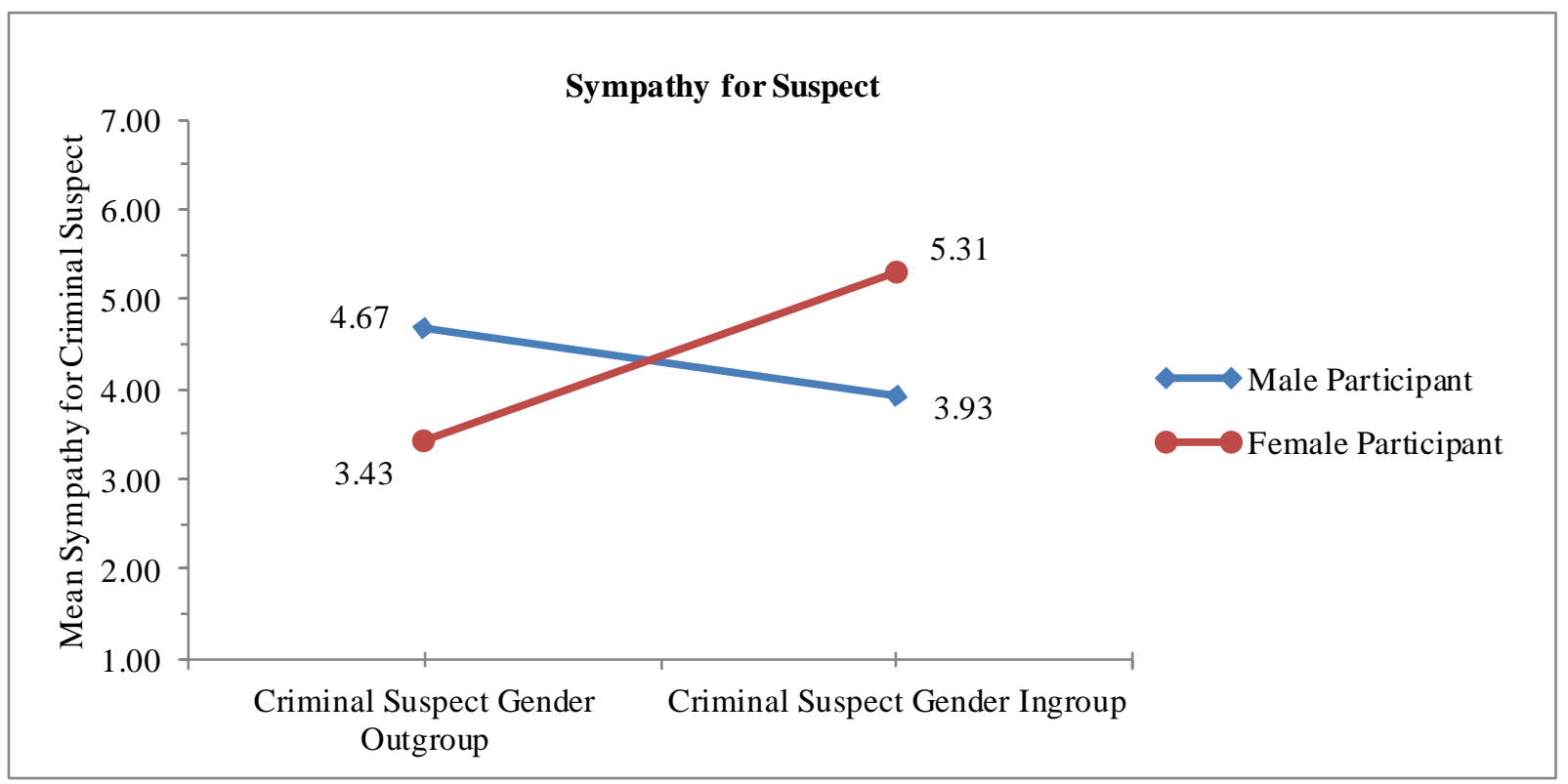

Figure A4. Participants' sympathy for criminal suspect. 


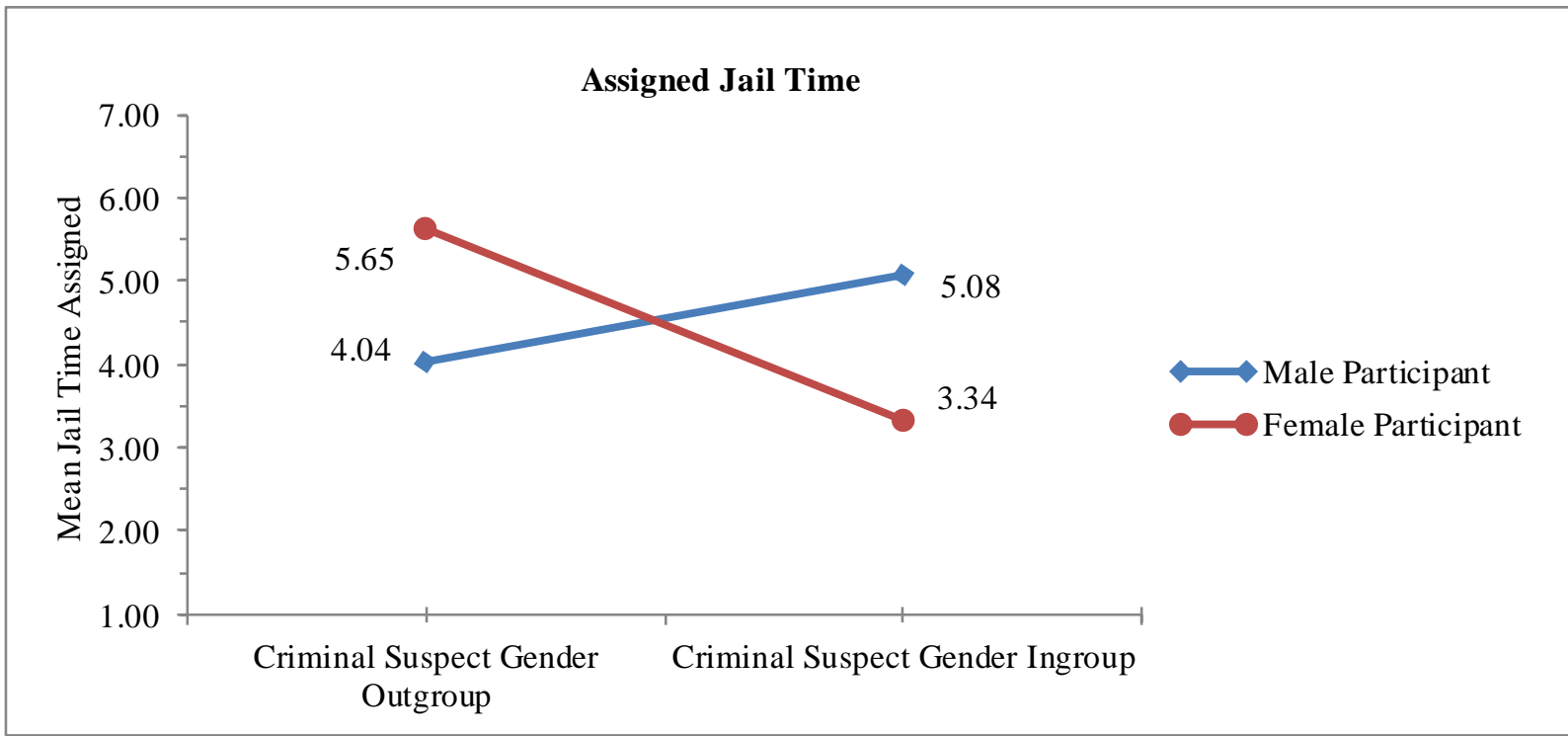

Figure A5. Participants' amount of Jail Time assigned to criminal suspect.

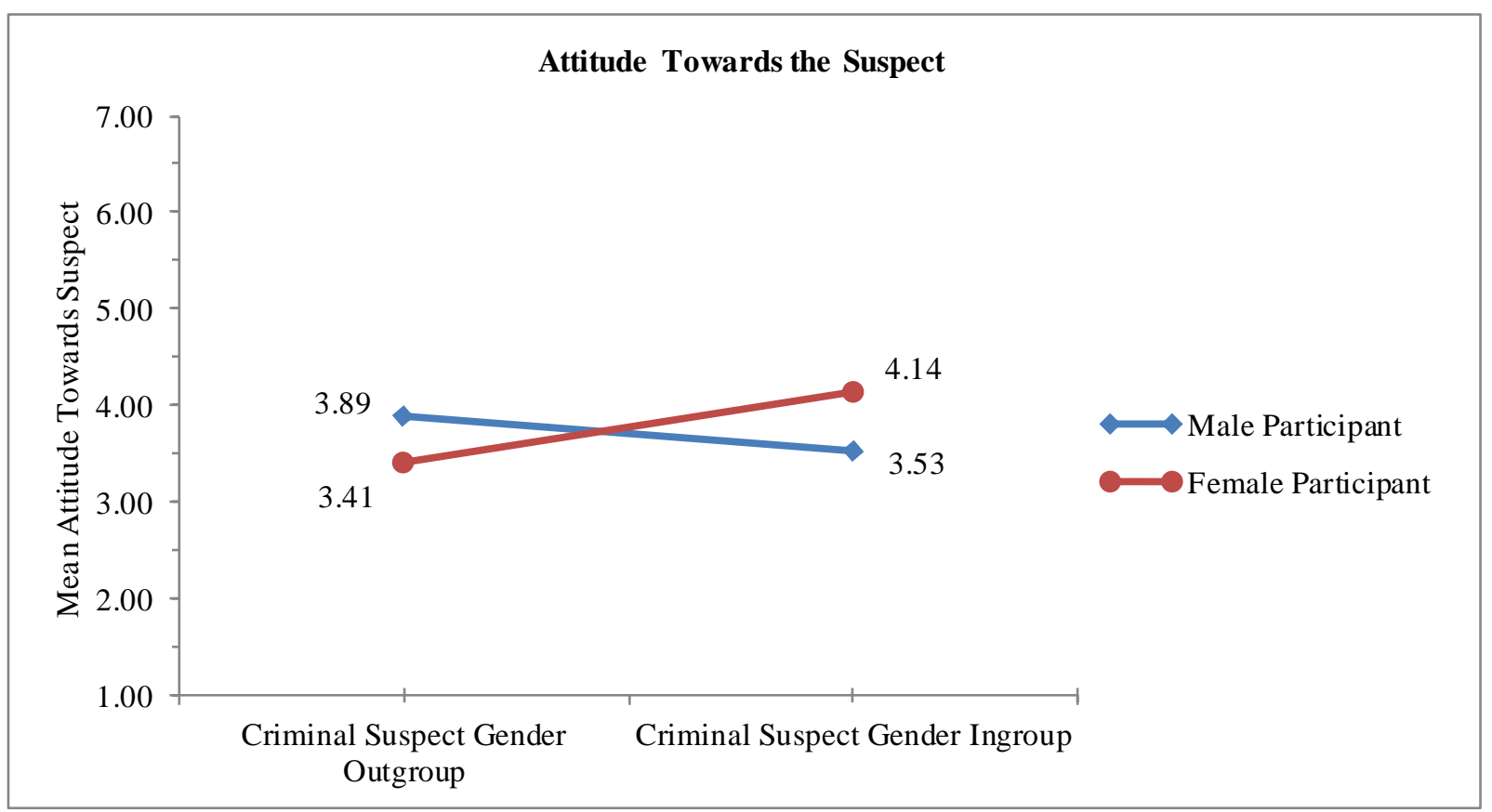

Figure A6. Participants' attitude towards the criminal suspect. 


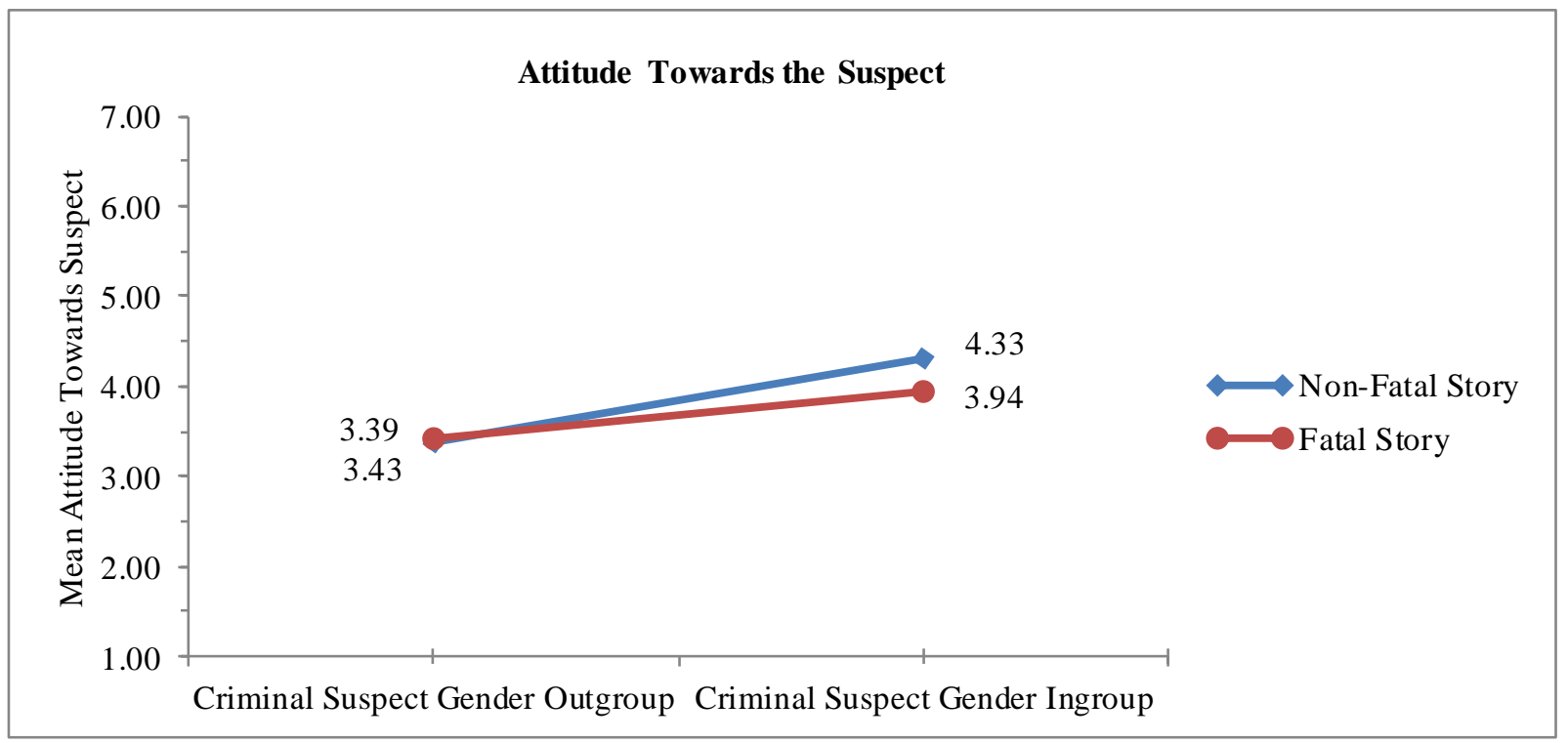

Figure A7. Female participants' attitude towards the criminal suspect based on story condition.

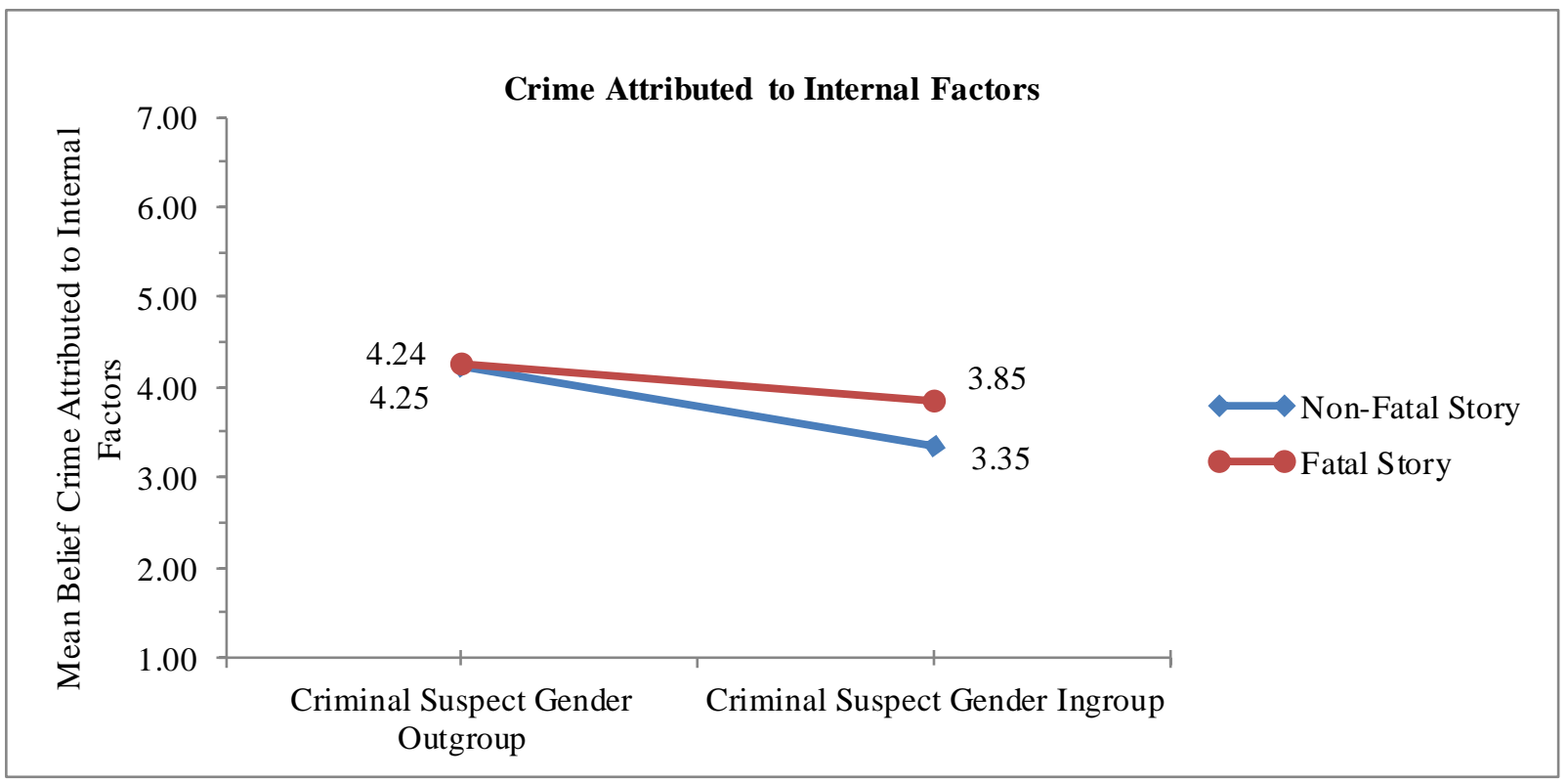

Figure A8. Female participants' belief crime was attributed to suspect's internal factors. 


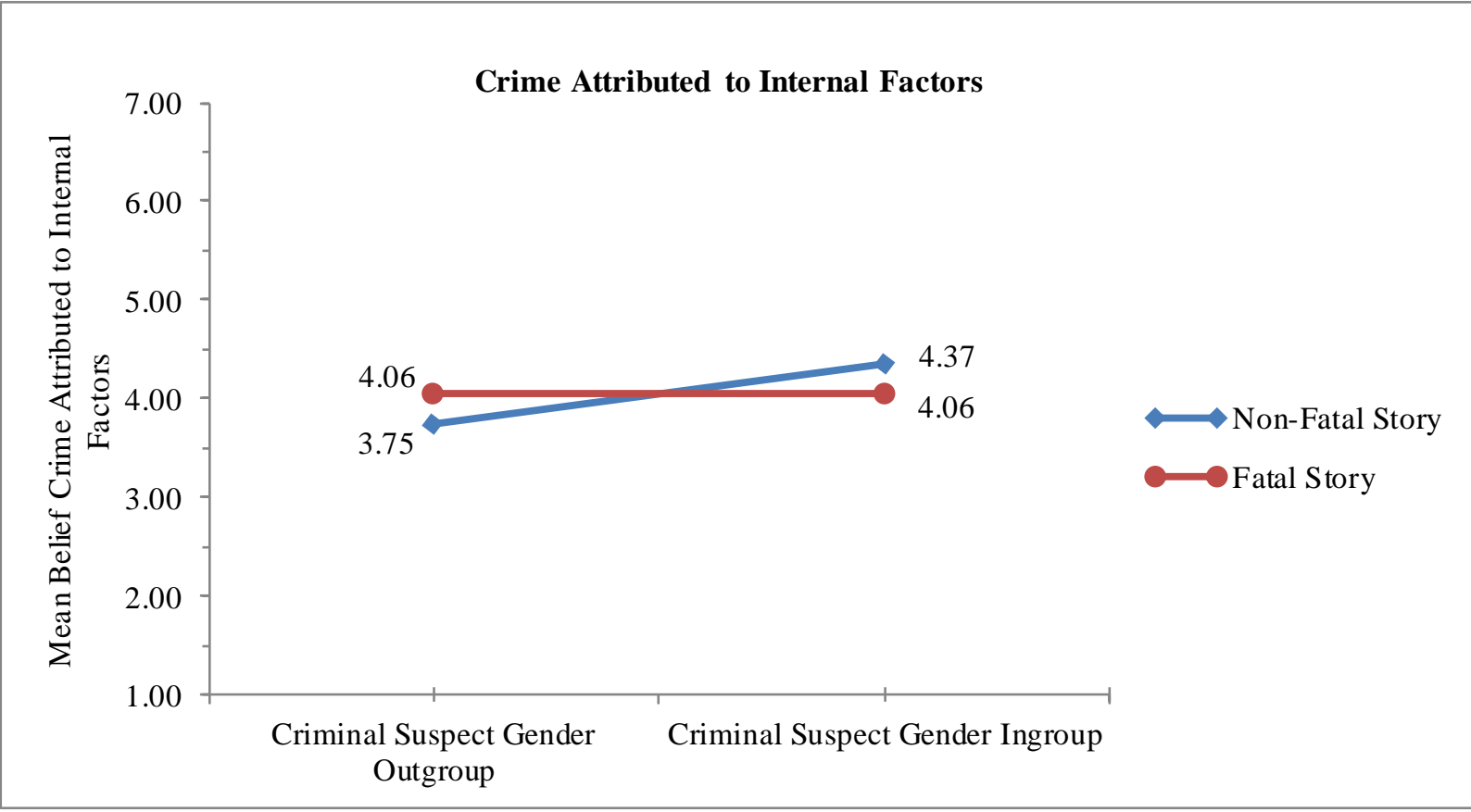

Figure A9. Male participants' belief crime was attributed to suspect's internal factors.

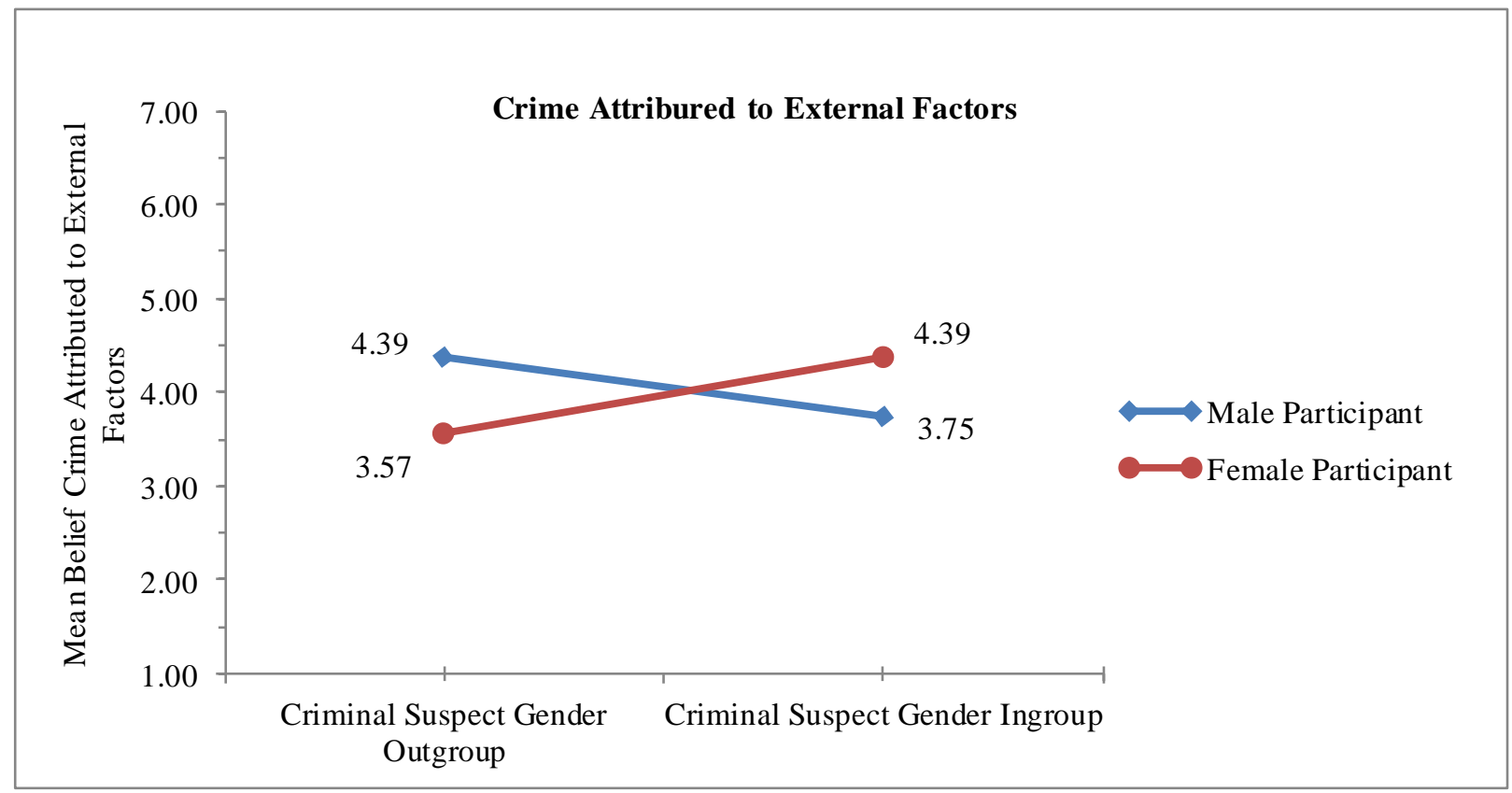

Figure A10. Male participants' belief crime was attributed to suspect's internal factors. 